\title{
Knowledge and Attitude towards COVID-19: A Cross Sectional Study in Bangladesh through Phone and Online Survey
}

${ }^{1}$ Chittagong Research Institute for Children Surgery, Chattogram, Bangladesh

2 Department of Surgery, Li Ka Shing Faculty of Medicine, University of Hong Kong, Hong Kong ${ }^{3}$ Department of Biomedical Sciences, City University of Hong Kong, Hong Kong

${ }^{4}$ Department of Medicine, Dhaka Medical College and Hospital, Dhaka, Bangladesh

Chit

Coittagong Medical College and Hospital,

Chattogram, Bangladesh

Department of Pathology, Li Ka Shing Faculty of

Medicine, University of Hong Kong, Hong Kong

${ }^{7}$ Department of Computer Science and

Engineering, International Islamic University

Chittagong, Bangladesh

${ }^{8}$ Department of Urban Planning and Design,

University of Hong Kong, Hong Kong

${ }^{9}$ Department of Urban and Regional Planning,

Jahangirnagar University, Dhaka, Bangladesh

${ }^{10}$ Department of Applied Food Science and

Nutrition, Chattogram Veterinary and Animal

Sciences University, Chattogram, Bangladesh

${ }^{11}$ Faculty of Agriculture, Hajee Mohammad

Danesh Science and Technology University,

Dinajpur, Bangladesh

${ }^{12}$ Department of Zoology, Government Hazi

Mohammad Mohsin College, National

University, Bangladesh

${ }^{13}$ Chattogram International Medical College,

Chattogram, Bangladesh

${ }^{14}$ Centre of Buddhist Studies, Faculty of Arts,

University of Hong Kong, Hong Kong

${ }^{15}$ Infectious Disease Division, International

Centre for Diarrhoeal Disease Research,

Bangladesh

${ }^{16}$ Department of Social and Preventive Medicine, Faculty of Medicine, Universiti Malaya, Malaysia ${ }^{17}$ Department of Physiology, Biochemistry and Pharmacology, Faculty of Veterinary Medicine, Chattogram Veterinary and Animal Sciences

University, Chattogram, Bangladesh

${ }^{18}$ Shaheed Suhrawardy Medical College and

Hospital, Dhaka, Bangladesh

${ }^{19}$ Independent Researcher, Chattogram,

Bangladesh

${ }^{20}$ Faculty of Veterinary Medicine, Chattogram

Veterinary and Animal Sciences University,

Chattogram, Bangladesh

${ }^{21}$ Department of Statistics, Shahjalal University of Science and Technology, Sylhet, Bangladesh

${ }^{22}$ Upazila Health and Family Planning Office,

Sadar, Gopalganj, Bangladesh

${ }^{23}$ School of Public Health, Li Ka Shing Faculty of

Medicine, University of Hong Kong, Hong Kon

${ }^{24}$ Department of Surgery, Chittagong Medical

College and Hospital, Chattogram, Bangladesh

Correspondence:

Tahmina Banu

Address: Chittagong Research Institute for Children Surgery, 29 Panchlaish,

Chattogram, Bangladesh

Email: proftahmina@gmail.com

Received: 18.07.2020,

Accepted: 17.08.2020

https://doi.org/10.29333/jcei/9143

Anwarul Karim ${ }^{1,2}$, Mastura Akter ${ }^{1,3}$, AHM Thafikul Mazid ${ }^{1,4}$, Orindom Shing Pulock ${ }^{1,5}$, Tasmiah Tahera Aziz Samira Hayee ${ }^{1}$, Nowrin Tamanna ${ }^{1}$, GS Chuwdhury ${ }^{6,7}$, Afsana Haque ${ }^{8,9}$, Farhana Yeasmin ${ }^{10}$, Mashkura Akter Mitu ${ }^{11}$, Farjana Yeasmin ${ }^{12}$, Humayun Rashid ${ }^{13}$, Ashish Kumar Kuri ${ }^{1,5}$, Arni Das ${ }^{1}$, Koushik Majumder ${ }^{5}$, Dipen Barua ${ }^{14}$, Md Mahabubur Rahaman ${ }^{15}$, Sanjida Akter ${ }^{16}$, Nashid Niaz Munia ${ }^{13}$, Jabin Sultana ${ }^{17}$, Faeeqa Usaila ${ }^{3}$, Sabrina Sifat ${ }^{18}$, Nishat Anjum Nourin ${ }^{1,5}$, Md Forhad Uddin ${ }^{19}$, Mrinmoy Bhowmik ${ }^{20}$, Tanvir Ahammed ${ }^{21}$, Nabil Sharik $^{22}$, Quddus Mehnaz ${ }^{23}$, Md Nur Hossain Bhuiyan ${ }^{24}$, Tahmina Banu ${ }^{1^{*}}$

\section{ABSTRACT}

Aim: This study investigated the knowledge and attitudes towards COVID-19 in Bangladeshi adults by online and phone survey methods during the early stage of its spread.

Methods: Data were collected through phone calls (April 14-23, 2020) and online survey (April 1819,2020 ) in Bangladesh. The questionnaire had 20 knowledge questions with each correct response getting one point and incorrect/don't know response getting no point (maximum total knowledge score 20). Participants scoring $>17$ were categorized as having good knowledge.

Results: The percentages of good knowledge holders were $57.6 \%, 75.1 \%$, and $95.8 \%$ in the phone, online non-medical, and online medical participants, respectively. Most of the phone and online participants had good knowledge of the preventive practices of COVID-19. However, among the non-medical participants (both phone and online), the correct response rates were lower than $80 \%$ for the knowledge questions asking about the facts that - some patients may have no symptoms, diarrhea is a symptom of this disease and that it cannot be prevented by any currently available medication. Male gender, higher education, living in town/urban areas, good financial condition, and use of internet were positively associated with higher knowledge score among the non-medical participants. However, higher knowledge score was associated with having less confidence in the final control of COVID-19.

Conclusion: Our study identified some COVID-19 information that were less known among the participants and the potential factors that were associated with having good versus poor knowledge. Besides, this study sheds light on the attitude of Bangladeshi adults towards COVID-19.

Keywords: knowledge, attitude, COVID-19, SARS-CoV-2, 2019-nCoV

\section{INTRODUCTION}

Severe Acute Respiratory Syndrome Coronavirus 2 (SARS-CoV-2), the causative pathogen for Coronavirus Disease 2019 (COVID-19), is spreading across the world in an unprecedented manner. It was first reported to the World Health Organization (WHO) on December 31, 2019. As of June 30,2020 , globally confirmed cases rose to 10577756 (with 513186 deaths) from 213 countries/territories/areas [1]. Bangladesh announced the first three cases of COVID19 on March 8, 2020. By June 30, 2020, the total number of confirmed cases raised to 145483 (with 1847 deaths) [1]. To reduce the spread of COVID-19 and chance of being infected, WHO advises public to adopt some simple precautions of maintaining hygiene and social distancing [2]. Authorities from different countries around the world are providing additional advice and adopting further measures e.g., complete or partial shutdown of different areas. An important determinant of peoples' adherence to these guidelines and measures could be the Knowledge, Attitudes, and Practices (KAP) towards COVID-19 of the respective population [3-5]. Furthermore, information about KAP of the general population may guide the policymakers and researchers tremendously to develop effective strategies to face this kind of rapidly evolving crisis.

Some COVID-19 KAP survey reports from different countries [1,6-10], including Bangladesh [11], are available already. However, most of these surveys were conducted through online questionnaire as it was not so feasible to do it otherwise 
during this pandemic disruption. Online surveys might have limitation in examining KAP in countries like Bangladesh, where only $15 \%$ of the population has access to internet compared to the world average of 50\% (World Bank - 2017) [12]. Therefore, KAP of the Bangladeshi adults towards COVID-19 especially during its initial rapid spread in Bangladesh is largely unknown and it was imperative to conduct further studies to understand more about it so that strategies can be developed or adapted accordingly. In this cross-sectional study, we surveyed adults from Bangladesh through phone call interviews and an online questionnaire during the initial rapid rise of COVID-19 in Bangladesh. The survey with phone calls had participants from more diverse sociodemographic backgrounds compared to the online survey. We present here the knowledge and attitude towards COVID-19 in Bangladeshi adults found by each survey method and the sociodemographic factors associated with them.

\section{METHODS}

Ethical clearance was obtained from the ethical review committee of Chittagong Medical College, Chattogram, Bangladesh. A cross-sectional survey was conducted through phone calls from April 14-23, 2020. In addition, an online survey was conducted from April 18-19, 2020. Details of the phone and online survey methods can be found in the Appendix 1.

\section{Measures}

The sociodemographic data collected in both phone and online surveys included the age in years $(\geq 18$ to $<35, \geq 35$ to $<55$, and $\geq 55$ ), gender (male, female, other), education level ( $\leq$ grade 5, grade 6 to $12,>$ grade 12 to Bachelor, $>$ Bachelor to Master/above), lived mostly in the last four months (rural, urban/town areas, other), self-reported financial condition (poor, middle-class, rich), and the administrative division of Bangladesh where the participant lived most of the life. Information about occupation (doctor/nurse/medical student, others) was asked in online survey. This auxiliary information allowed us to stratify the online survey participants into "online non-medical" and "online medical" groups. Because participants of $<18$ years old could not be restricted from attempting the online questionnaire, we added one more age category $(<18$ years $)$ in the online survey. This enabled us to exclude them from data analysis as our targets were the participants of $\geq 18$ years old.

The questionnaire (provided in Appendix 1) had three main sections: Section-1 asked about the source of information regarding COVID-19 or SARS-CoV-2. Section2 (knowledge section) had two subdivisions: Section-2A (questions related to the knowledge of disease) and Section2B (questions related to the knowledge of preventive practices). Section-3 (attitude section) was used only for the online survey. In Section-2A, there were 14 questions (KD01 to KD14) related to the Knowledge of Disease that included signs/symptoms, mode of spread, outcome of the disease etc.
In Section-2B, there were six questions (KP01 to KP06) related to the Knowledge of Preventive practices. In Section3 , there were two attitude questions (A1 and A2). Options to the knowledge questions were a) true, b) false, and c) don't know. Options to the attitude questions were a) yes, b) no, and c) don't know. A correct response to a knowledge question was assigned 1 point and an incorrect/don't know response was assigned 0 point. Total score of Knowledge of Disease (KD) and Knowledge of Preventive practices (KP) ranged from 0 to 14 and 0 to 6 , respectively. Therefore, the total knowledge score ranged from 0-20. A higher score indicated a higher knowledge level. The Cronbach's alpha coefficient of the knowledge questionnaire was 0.74 in the current study, indicating acceptable internal consistency $[5,13]$.

\section{Statistical Analysis}

Data analysis was performed with IBM SPSS Statistics 20. We divided the survey participants into three main groups as "phone", "online non-medical", and "online medical". Frequencies and percentages were used to describe the responses to the questions and sociodemographic characteristics of the participants. Chi-square test for independence and Mann-Whitney $U$ test were used for comparison between different groups wherever appropriate. Correlations among KD, KP, and total knowledge scores were investigated with Spearman's correlation. Binary or multinomial logistic regression was used as appropriate to identify factors associated with total knowledge score and attitudes. The statistical significance level was set at $P<0.05$ (two-sided). Bonferroni correction of $P$ values was done as appropriate in case of multiple testing.

\section{RESULTS}

There were 1427 phone participants (all from nonmedical background). All of them heard about COVID-19 except one. In the online survey, we had a total of 1521 participants and $98.6 \%$ (1500) of them heard about the disease. From these 1500 online participants, 19 were excluded because of being less than 18 years old. Two more participants were excluded because they reported their education level as $\leq 12^{\text {th }}$ grade but reported themselves as doctor/nurse/medical student. The results presented hereafter are based on the final dataset of 1426 phone participants and 1479 online participants. Among these 1479 online participants, 382 were from medical background and the remaining 1097 were from non-medical.

\section{Socio-demographic Characteristics and Sources of COVID-19 Information}

The administrative division-wise distribution of the participants is given in Appendix 2. We had participants from all the divisions of Bangladesh in both phone and online surveys with most of the participants from the two major divisions Chattogram and Dhaka. The other sociodemographic characteristics are shown in Table 1. Chisquare test for independence showed that all the 
Knowledge and attitude towards COVID-19 in Bangladesh

Table 1. Socio-demographic characteristics of the participants

\begin{tabular}{|c|c|c|c|c|c|}
\hline \multirow{2}{*}{\multicolumn{2}{|c|}{ Socio-demographic characteristics }} & Phone $n=1426$ & Online non-medical $n=1097$ & Online medical $n=382$ & \multirow{2}{*}{$\chi^{2} P$-value } \\
\hline & & $n(\%)$ & $\mathrm{n}(\%)$ & $n(\%)$ & \\
\hline \multirow{3}{*}{ Age (years) } & $\geq 18-<35$ & 811 (56.9) & $901(82.1)$ & $347(90.8)$ & \multirow{3}{*}{$<0.001$} \\
\hline & $\geq 35-<55$ & $427(29.9)$ & $173(15.8)$ & $28(7.3)$ & \\
\hline & $\geq 55$ & $188(13.2)$ & $23(2.1)$ & $7(1.8)$ & \\
\hline \multirow{3}{*}{ Gender } & Male & $798(56)$ & $743(67.7)$ & $161(42.1)$ & \multirow{3}{*}{$<0.001$} \\
\hline & Female & $627(44)$ & $354(32.3)$ & 221 (57.9) & \\
\hline & Other & $1(0.1)$ & $0(0)$ & $0(0)$ & \\
\hline \multirow{4}{*}{ Education } & $\leq$ Grade 5 & $179(12.6)$ & $2(0.2)$ & $0(0)$ & \multirow{4}{*}{$<0.001$} \\
\hline & Grade 6 to $12\left(\mathrm{HSC}^{\mathrm{a}}\right)$ & $433(30.4)$ & $65(5.9)$ & $0(0)$ & \\
\hline & $>$ Grade 12 to Bachelor & $560(39.3)$ & $571(52.1)$ & $269(70.4)$ & \\
\hline & > Bachelor to Master or above & $254(17.8)$ & $459(41.8)$ & $113(29.6)$ & \\
\hline \multirow{3}{*}{$\begin{array}{l}\text { Lived mostly in last } \\
\quad 4 \text { months }\end{array}$} & Rural & $399(28)$ & $127(11.6)$ & $38(9.9)$ & \multirow{3}{*}{$<0.001$} \\
\hline & Urban/town & $1016(71.2)$ & $950(86.6)$ & $340(89)$ & \\
\hline & Other & $11(0.8)$ & $20(1.8)$ & $4(1)$ & \\
\hline \multirow{3}{*}{ Financial condition ${ }^{b}$} & Poor & $240(16.8)$ & $45(4.1)$ & $0(0)$ & \multirow{3}{*}{$<0.001$} \\
\hline & Middle-class & 1125 (78.9) & 1012 (92.3) & 351 (91.9) & \\
\hline & Rich & $61(4.3)$ & $40(3.6)$ & $31(8.1)$ & \\
\hline
\end{tabular}

aHigher Secondary Certificate exam

belf-reported financial condition of the family of participant
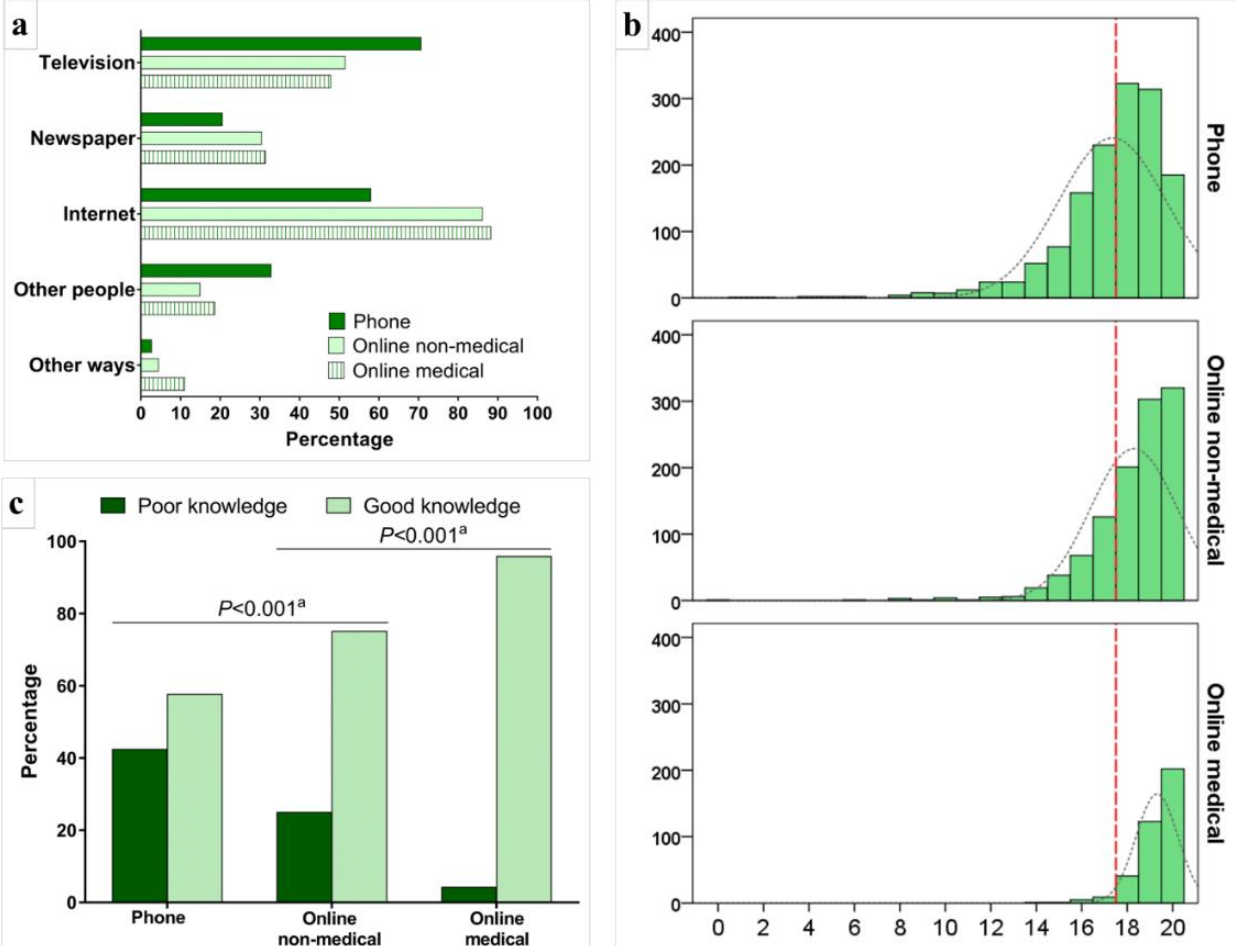

Figure 1. Sources of information according to the participant groups (1a), distribution of total knowledge scores (1b), and percentage of poor vs. good knowledge holders in each participant group (1c)

1a. Majority of the participants mentioned internet and television as the sources of information of COVID-19. 1b. Participants were dichotomized into "poor knowledge" or "good knowledge" holders if the total knowledge score was $\leq 17$ ( $\leq 85 \%$ ) or $>17$, respectively. This is because we assumed that most of the medical participants should have good knowledge of COVID-19, and score of $>17$ covered $95.8 \%$ of the medical participants as good knowledge holders. $1 \mathrm{c}$. The percentage of good knowledge holders were significantly lower in the phone participant group compared to the online non-medical group.

${ }^{a}$ Chi-square test for independence (with Yates Continuity Correction)

characteristics differed significantly between participant groups. The participants of the phone survey were less educated and from poorer families compared to the online participants. A significantly higher portion of the online participants had been living in urban/town areas (vs. rural) for the last four months compared to the phone survey participants. Also, the online survey had comparatively more young participants than phone survey. Both phone and online survey participants mentioned internet and television as major sources of information of COVID-19 (Figure 1a). 
Table 2. Percentage of the correct response to each question of the knowledge questionnaire

\begin{tabular}{|c|c|c|c|c|c|c|}
\hline \multirow{3}{*}{ Items } & & 1 & 2 & 3 & 1 vs. 2 & 2 vs. 3 \\
\hline & & $\begin{array}{l}\text { Phone } \\
n=1426\end{array}$ & $\begin{array}{c}\text { Online } \\
\text { non- } \\
\text { medical } \\
n=1097\end{array}$ & $\begin{array}{c}\text { Online } \\
\text { medical } \\
n=382\end{array}$ & \multicolumn{2}{|c|}{ Chi-square test } \\
\hline & & $\%$ & $\%$ & $\%$ & $P^{b}$ & $P^{b}$ \\
\hline \multicolumn{7}{|c|}{ Questions related to the knowledge of the disease (KD) } \\
\hline KD01 & Some patients may have no symptoms & 54.3 & 71.1 & 94.2 & $<0.001$ & $<0.001$ \\
\hline KD02 & Fever is a common symptom of this disease & 89.7 & 86.0 & 93.2 & 0.202 & 0.011 \\
\hline$\overline{\mathrm{KD03}}$ & Cough is a common symptom of this disease & 87.8 & 86.2 & 94.5 & $>0.99$ & $<0.001$ \\
\hline KD04 & Patients with this disease can suffer from shortness of breath or difficulty in breathing & 93.4 & 96.6 & 99.2 & 0.017 & 0.494 \\
\hline KD05 & Some patients with this disease can have tiredness, sore throat, headaches, body aches & 86.5 & 92.6 & 96.9 & $<0.001$ & 0.192 \\
\hline KD06 & Some patients with this disease can have diarrhea & 56.6 & 77.8 & 88 & $<0.001$ & $<0.001$ \\
\hline KD07 & This disease can be completely prevented by taking antibiotics or other medicine & 64.1 & 77.2 & 94.2 & $<0.001$ & $<0.001$ \\
\hline KD08 & It can take up to 14 days after being infected to develop symptoms & 86.8 & 92.3 & 95.5 & $<0.001$ & $>0.99$ \\
\hline KD09 & The disease can spread from an infected person to others even before symptoms develop & 84.4 & 95.3 & 99.5 & $<0.001$ & $<0.012$ \\
\hline KD10 & This virus can spread from an infected person through talking or breathing & 82.3 & 76.2 & 88 & 0.007 & $<0.001$ \\
\hline KD11 & This virus can spread from an infected person through coughing & 96.6 & 97.9 & 99 & $>0.99$ & $>0.99$ \\
\hline KD12 & $\begin{array}{l}\text { People can get infected by touching objects or surfaces contaminated with this virus, and } \\
\text { then touching their eyes, nose or mouth without cleaning hands }\end{array}$ & 96.6 & 99.1 & 99.2 & 0.003 & $>0.99$ \\
\hline KD13 & All the patients with this disease die & 83.6 & 97.6 & 100 & $<0.001$ & 0.198 \\
\hline KD14 & $\begin{array}{l}\text { Older persons and persons with heart disease, lung disease, diabetes are at high risk of } \\
\text { developing severe COVID-19 disease }\end{array}$ & 93.1 & 94.3 & 98.7 & $>0.99$ & 0.030 \\
\hline \multicolumn{7}{|c|}{ Questions related to the knowledge of the preventive practices (KP) } \\
\hline KP01 & Younger persons do not need to follow any precautionary measures to prevent the disease & 86.9 & 95.0 & 96.9 & $<0.001$ & $>0.99$ \\
\hline KP02 & $\begin{array}{l}\text { Washing hands frequently and thoroughly with soap or alcohol-based hand sanitizers } \\
\text { reduces the risk of being infected by this virus }\end{array}$ & 98.9 & 99.1 & 99 & $>0.99$ & $>0.99$ \\
\hline KP03 & $\begin{array}{l}\text { To reduce the risk of being infected by this virus, one should avoid touching eyes, nose, } \\
\text { mouth with uncleaned hands }\end{array}$ & 98.4 & 98.5 & 98.4 & $>0.99$ & $>0.99$ \\
\hline KP04 & $\begin{array}{l}\text { To reduce the spread of this virus, one should cover his mouth and nose with bent-elbow } \\
\text { or tissue paper or handkerchief when coughing or sneezing }\end{array}$ & 99.1 & 99.9 & 99.7 & 0.526 & $>0.99$ \\
\hline KP05 & $\begin{array}{l}\text { When this virus spreads in an area, people should stay home as much as possible to reduce } \\
\text { the spread of this disease }\end{array}$ & 99.0 & 99.2 & 99.5 & $>0.99$ & $>0.99$ \\
\hline KP06 & Infected person should wear mask to reduce the spread of this virus & 96.8 & 97.5 & 97.6 & $>0.99$ & $>0.99$ \\
\hline
\end{tabular}

${ }^{\mathrm{b}}$ Bonferroni corrected $P$ values. $P$ values that are significant at $<0.05$ are made bold.

\section{Correct Response Rates to the Knowledge Questions}

The correct response rates to the 20 knowledge questions ranged $54.3-99.1 \%, 71.1-99.9 \%$, and $88-100 \%$ in the phone, online non-medical, and online medical participants, respectively (Table 2). Chi-square test for independence showed that the correct response rates differed significantly for 10 out of $14 \mathrm{KD}$ questions between the phone survey data and online non-medical survey data. In general, for questions having significantly different correct response rates, the rates were higher in online survey compared to that of the phone survey, except for one questions (KD10). In addition, for 8 out of $14 \mathrm{KD}$ questions, correct response rates were significantly higher for the online medical group than online non-medical. Despite this difference in KD among the participant groups, correct response rates in the $\mathrm{KP}$ questions showed less difference except for one (KP01) question. Overall, among the non-medical participants (both phone and online), the correct response rates were lower than $80 \%$ for the knowledge questions asking about the facts that - some patients may have no symptoms, diarrhea is a symptom of this disease and that it cannot be prevented by any currently available medication.

\section{Categorization of Participants into Poor or Good}

\section{Knowledge Holders}

Participants were categorized into "poor knowledge" or "good knowledge" holders based on the total knowledge score achieved ( $\leq 17$ and $>17-20$ respectively) (Figure $\mathbf{1 b}$ and Figure 1c). This is because we assumed that most of the medical participants should have good knowledge of COVID-19, and score of $>17$ covered $95.8 \%$ of the medical participants as good knowledge holders. The percentage of good knowledge holders among the phone participants was $57.6 \%$, whereas, it was $75.1 \%$ for the online non-medical participant group (Figure 1c).

\section{Total Knowledge Score}

The total knowledge scores based on sociodemographic characteristics and sources of COVID-19 information are shown in Table 3. Online medical participants achieved the highest total knowledge score (median 20, IQR 19-20). It was 
Knowledge and attitude towards COVID-19 in Bangladesh

Table 3. Total knowledge score according to the sociodemographic characteristics and source of information

\begin{tabular}{|c|c|c|c|c|c|c|}
\hline & & 1 & 2 & 3 & 1 vs. 2 & 2 vs. 3 \\
\hline & & Phone $n=1426$ & $\begin{array}{l}\text { Online non-medical } \\
\qquad n=1097\end{array}$ & $\begin{array}{l}\text { Online medical } \\
\quad n=382\end{array}$ & \multicolumn{2}{|c|}{ Mann-Whitney U test } \\
\hline & & Median (IQR) & Median (IQR) & Median (IQR) & $\boldsymbol{P}^{a}$ & $P^{a}$ \\
\hline \multicolumn{7}{|c|}{ Socio-demographic characteristics } \\
\hline \multirow[t]{3}{*}{ Age (years) } & $\geq 18-<35$ & $18(17-19)$ & $19(17-20)$ & $20(19-20)$ & $<0.001$ & $<0.001$ \\
\hline & $\geq 35-<55$ & $17(16-19)$ & $19(18-20)$ & $20(19-20)$ & $<0.001$ & 0.118 \\
\hline & $\geq 55$ & $18(16-19)$ & $19(17-20)$ & $20(19-20)$ & $>0.99$ & $>0.99$ \\
\hline \multirow[t]{2}{*}{ Gender } & Male & $18(17-19)$ & $19(18-20)$ & $20(19-20)$ & $<0.001$ & $<0.001$ \\
\hline & Female & $18(16-19)$ & $19(17-20)$ & $20(19-20)$ & $<0.001$ & $<0.001$ \\
\hline \multirow[t]{4}{*}{ Education } & $\leq$ Grade 5 & $16(13-18)$ & 17.5 & & & \\
\hline & Grade 6 to 12 & $17(16-18)$ & $18(16-19)$ & & $>0.99$ & \\
\hline & $>$ Grade 12 to Bachelor & $18(17-19)$ & 19 (17-19) & $19(19-20)$ & 0.241 & $<0.001$ \\
\hline & > Bachelor to Master or above & $19(17-19.25)$ & $19(18-19)$ & $20(19-20)$ & $<0.001$ & $<0.001$ \\
\hline \multirow{3}{*}{$\begin{array}{l}\text { Lived mostly in last } \\
4 \text { months }\end{array}$} & Village & $17(16-19)$ & $18(17-19)$ & $20(19-20)$ & $<0.001$ & $<0.001$ \\
\hline & Urban/town & $18(17-19)$ & $19(18-20)$ & $20(19-20)$ & $<0.001$ & $<0.001$ \\
\hline & Other & $18(16-19)$ & $19(18-20)$ & $19.5(17.5-20)$ & $>0.99$ & $>0.99$ \\
\hline \multirow[t]{3}{*}{ Financial condition } & Poor & $17(14-18)$ & $19(17-19)$ & & $<0.001$ & \\
\hline & Middle-class & $18(17-19)$ & $19(18-20)$ & $20(19-20)$ & $<0.001$ & $<0.001$ \\
\hline & Rich & $18(17-19)$ & $19(18-20)$ & $20(19-20)$ & $>0.99$ & $>0.99$ \\
\hline \multicolumn{7}{|c|}{ Source of information } \\
\hline \multirow[t]{2}{*}{$\begin{array}{l}\text { Television } \\
\end{array}$} & Yes & $18(16-19)$ & $19(17-20)$ & $20(19-20)$ & $<0.001$ & $<0.001$ \\
\hline & No & $18(16-19)$ & $19(18-20)$ & $20(19-20)$ & $<0.001$ & $<0.001$ \\
\hline \multirow[t]{2}{*}{ Newspaper } & Yes & $18(17-19)$ & $19(18-20)$ & $20(19-20)$ & $<0.001$ & $<0.001$ \\
\hline & No & $18(16-19)$ & $19(17-20)$ & $20(19-20)$ & $<0.001$ & $<0.001$ \\
\hline \multirow[t]{2}{*}{ Internet } & Yes & $18(17-19)$ & $19(18-20)$ & $20(19-20)$ & $<0.001$ & $<0.001$ \\
\hline & No & $17(16-18)$ & $19(17-19.75)$ & $19(18-20)$ & $<0.001$ & 0.423 \\
\hline \multirow[t]{2}{*}{ Other people } & Yes & $17(16-19)$ & $19(18-20)$ & $20(19-20)$ & $<0.001$ & $<0.001$ \\
\hline & No & $18(17-19)$ & $19(17.75-20)$ & $20(19-20)$ & $<0.001$ & $<0.001$ \\
\hline \multirow[t]{2}{*}{ Other ways } & Yes & $18(17-19)$ & $19(18-20)$ & $20(19-20)$ & 0.032 & $>0.99$ \\
\hline & No & $18(16-19)$ & $19(17-20)$ & $20(19-20)$ & $<0.001$ & $<0.001$ \\
\hline Total & & $18(16-19)$ & $19(18-20)$ & $20(19-20)$ & $<0.001$ & $<0.001$ \\
\hline
\end{tabular}

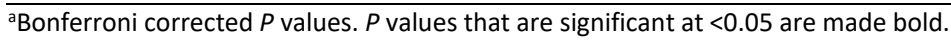

followed by the online non-medical group (median 19, IQR 18-20). The phone participants scored the least (median 18, IQR 16-19). The median scores for almost all categories of sociodemographic characteristics and sources of information were higher in online non-medical participants compared to that of the phone participants with most of the differences being statistically significant.

\section{Correlations among KD, KP, and Total Knowledge}

\section{Score}

Spearman's correlation coefficient showed that there was a weak positive association (coefficient $0.2, P$ value $<0.001$ ) between KD score and KP score. Whereas KP had a moderate correlation with Total knowledge score (coefficient $0.36, \mathrm{P}$ value $<0.001$ ), KD had a nearly perfect correlation with the total knowledge score with a coefficient of 0.98 ( $P$ value $<0.001$ ) and thereby explaining $96.2 \%$ of the variance in the total knowledge score. Taken together with the high correct response rates to five of the six KP questions (as shown in Table 2), it suggests that most participants had good knowledge of the preventive practices irrespective of their knowledge level of the disease.

\section{Factors Associated with having Good COVID-19}

\section{Knowledge}

Binary logistic regression analysis of the combined dataset of non-medical participants of phone and online surveys showed that, male gender (vs. female), higher education (vs. $\leq$ grade 12), living in town for the last four months (vs. living in rural areas), middle-class/rich financial condition (vs. poor), and internet as a source of information (vs. not as a source) were positively associated with having good knowledge (vs. poor knowledge) (Table 4).

\section{Attitude towards COVID-19 and Associated Factors}

Responses to the attitude questions are shown in Table 5 (responses by sociodemographic characteristics and source of information are shown in Appendix 3 and Appendix 4). Among the online non-medical and online medical participants, $61.1 \%$ and $56 \%$ respectively were optimistic that this new coronavirus will finally be controlled completely (attitude question A1). Multinomial logistic 
Knowledge and attitude towards COVID-19 in Bangladesh

Table 4. Results of binary logistic regression on factors predicting the likelihood of having good knowledge among the non-medical participants

\begin{tabular}{|c|c|c|c|c|c|c|c|c|c|}
\hline \multirow{2}{*}{\multicolumn{2}{|c|}{ Factors }} & \multirow{3}{*}{$\begin{array}{c}\text { B } \\
0.09\end{array}$} & \multirow{3}{*}{$\begin{array}{l}\text { S.E. } \\
0.12\end{array}$} & \multirow{3}{*}{$\begin{array}{c}\text { Wald } \\
0.58\end{array}$} & \multirow{3}{*}{$\begin{array}{l}\text { df } \\
1\end{array}$} & \multirow{3}{*}{$\begin{array}{c}P \\
0.445\end{array}$} & \multirow{3}{*}{$\begin{array}{c}\begin{array}{c}\text { Odds } \\
\text { Ratio }\end{array} \\
1.10\end{array}$} & \multicolumn{2}{|c|}{ 95\% C.I. for Odds Ratio } \\
\hline & & & & & & & & Lower & Upper \\
\hline \multirow{2}{*}{ Age } & $\geq 35$ to $<55$ vs $\geq 18$ to $<35$ & & & & & & & 0.87 & 1.39 \\
\hline & $\geq 55$ vs $\geq 18$ to $<35$ & 0.25 & 0.17 & 1.99 & 1 & 0.158 & 1.28 & 0.91 & 1.80 \\
\hline Gender & Male vs. Female & 0.31 & 0.09 & 11.12 & 1 & 0.001 & 1.36 & 1.14 & 1.63 \\
\hline \multirow{2}{*}{ Education } & $>\mathrm{HSC}$ to Bachelor vs. $\leq \mathrm{HSC}$ & 0.58 & 0.13 & 19.98 & 1 & $<0.001$ & 1.79 & 1.39 & 2.31 \\
\hline & $>$ Bachelor vs. $\leq \mathrm{HSC}$ & 1.22 & 0.15 & 69.80 & 1 & $<0.001$ & 3.38 & 2.54 & 4.49 \\
\hline Lived in last 4 months & Town vs. Rural & 0.26 & 0.11 & 5.40 & 1 & 0.020 & 1.30 & 1.04 & 1.62 \\
\hline Financial condition & Middle-class/Rich vs. Poor & 0.34 & 0.15 & 5.13 & 1 & 0.024 & 1.41 & 1.05 & 1.90 \\
\hline \multirow{5}{*}{ Source of information } & Television (yes vs. no) & 0.04 & 0.10 & 0.12 & 1 & 0.727 & 1.04 & 0.85 & 1.27 \\
\hline & Newspaper (yes vs. no) & 0.16 & 0.12 & 1.92 & 1 & 0.166 & 1.18 & 0.93 & 1.49 \\
\hline & Internet (yes vs. no) & 0.58 & 0.11 & 25.78 & 1 & $<0.001$ & 1.79 & 1.43 & 2.24 \\
\hline & Other people (yes vs. no) & -0.14 & 0.11 & 1.65 & 1 & 0.200 & 0.87 & 0.70 & 1.08 \\
\hline & Other ways (yes vs. no) & 0 & 0.27 & 0 & 1 & $>0.99$ & 1.00 & 0.60 & 1.69 \\
\hline \multicolumn{2}{|c|}{ Constant } & -1.09 & 0.19 & 31.68 & 1 & $<0.001$ & 0.34 & & \\
\hline
\end{tabular}

$P$ values less than 0.05 are made bold

Table 5. Responses to the attitude questions

\begin{tabular}{|c|c|c|c|c|c|c|c|}
\hline \multirow{2}{*}{ Attitude questions } & & \multicolumn{3}{|c|}{ Online non-medical, n=1097 } & \multicolumn{3}{|c|}{ Online medical, $n=382$} \\
\hline & & Yes & No & Don't know & Yes & No & Don't know \\
\hline $\begin{array}{l}\text { A1. Do you think that this new coronavirus will } \\
\text { finally be under control completely? }\end{array}$ & $\mathrm{n}(\%)$ & $670(61.1)$ & $119(10.8)$ & 308 (28.1) & $214(56)$ & $63(16.5)$ & $105(27.5)$ \\
\hline $\begin{array}{l}\text { A2. "This virus is created by humans" - this kind of } \\
\text { discourse is heard. Do you believe that it is true? }\end{array}$ & $\mathrm{n}(\%)$ & $210(19.1)$ & $280(25.5)$ & $607(55.3)$ & $69(18.1)$ & $138(36.1)$ & $175(45.8)$ \\
\hline
\end{tabular}

Table 6. Multinomial logistic regression analysis on factors predicting the likelihood of different responses of attitude questions

\begin{tabular}{|c|c|c|c|c|c|c|c|c|}
\hline \multirow{2}{*}{ Factors $^{\mathrm{a}}$} & \multirow{2}{*}{ B } & \multirow{2}{*}{ S.E. } & \multirow{2}{*}{ Wald } & \multirow{2}{*}{ df } & \multirow{2}{*}{$\boldsymbol{P}$} & \multirow{2}{*}{ Odds Ratio } & \multicolumn{2}{|c|}{ 95\% C.I. for Odds Ratio } \\
\hline & & & & & & & Lower & Upper \\
\hline \multicolumn{9}{|c|}{ A1. Do you think that this new coronavirus will finally be under control completely? (no vs. yes) } \\
\hline Total knowledge score & 0.17 & 0.07 & 6.03 & 1 & 0.014 & 1.19 & 1.04 & 1.36 \\
\hline Use internet as source of information (yes vs no) & 1.08 & 0.42 & 6.50 & 1 & 0.011 & 2.95 & 1.28 & 6.78 \\
\hline \multicolumn{9}{|c|}{ A1. Do you think that this new coronavirus will finally be under control completely? (don't know vs. yes) } \\
\hline Gender (female vs male) & 0.48 & 0.15 & 10.02 & 1 & 0.002 & 1.62 & 1.20 & 2.18 \\
\hline \multicolumn{9}{|c|}{ A1. Do you think that this new coronavirus will finally be under control completely? (don't know vs. no) } \\
\hline Gender (female vs male) & 0.63 & 0.25 & 6.23 & 1 & 0.013 & 1.87 & 1.14 & 3.06 \\
\hline \multicolumn{9}{|c|}{ A2. "This virus is created by humans" - this kind of discourse is heard. Do you believe that it is true? (no vs. yes) } \\
\hline Total knowledge score & 0.12 & 0.05 & 5.21 & 1 & 0.023 & 1.13 & 1.02 & 1.25 \\
\hline \multicolumn{9}{|c|}{ A2. "This virus is created by humans" - this kind of discourse is heard. Do you believe that it is true? (no vs. don't know) } \\
\hline Total knowledge score & 0.12 & 0.05 & 6.97 & 1 & 0.008 & 1.14 & 1.03 & 1.23 \\
\hline
\end{tabular}

${ }^{a}$ All the independent variables shown in Table 4 were also used here with one additional independent variable (Total knowledge score). Only the significantly associated variables are shown in this table.

regression analysis showed that for every unit increase in the total knowledge score, the odds of the participants responding "no" (compared to responding "yes") increased by a factor of 1.19 (95\% CI 1.04 to 1.36), all other factors being equal (Table 6). Similarly, the odds of a participant responding "no" (compared to "yes") was 2.95 times higher (95\% CI 1.28 to 6.78) for someone who reported the internet as a source of information than for a participant who did not, all other factors being equal. Interestingly, females had higher odds of responding "don't know" (compared to "yes" or "no") to this attitude question than males.
In case of attitude question A2 ("This virus is created by humans" - this kind of discourse is heard. Do you believe that it is true?), only $25.5 \%$ and $36.1 \%$ of the online non-medical and online medical participants, respectively, believed that the virus was not created by humans (Table 5). Most of the participants responded "don't know" to this attitude question. Multinomial logistic regression analysis showed that for every unit increase in the total knowledge score, the odds of the participants responding "no" increased by a factor of 1.13 or 1.14 (compared to responding "yes" or 
"don't know", respectively), all other factors being equal (Table 6).

\section{DISCUSSION}

It is imperative to know the knowledge and attitude of the population towards COVID-19 to develop effective strategies in fighting the ongoing pandemic. Several studies investigating the knowledge and attitudes have been published from different countries. Given the social distancing measures in place in most countries, majority of these COVID-19 KAP surveys have been conducted through internet with some exceptions [14]. In this study, we presented data from phone survey in addition to the online survey to obtain a better representation of the Bangladeshi adults.

In our study, the sociodemographic characteristics were significantly different between the phone and online participants. The phone survey method was able to include more participants from poor, rural, and less educational backgrounds compared to the online survey. We found that the total knowledge score was higher in the online nonmedical participant group than that of phone survey participants in most of the socio-demographic categories. In addition to the difference in the population characteristics in both survey types, another possible reason for this finding could be that the online participants probably had more opportunity to know the correct answers from others or by searching elsewhere than the phone survey participants who responded immediately to the survey questions during the phone calls.

We found that although majority of the non-medical participants were aware of most of the important information provided by the leading health authorities at the time of the study period, they were less aware about some COVID-19 information which includes the facts that - some patients may have no symptoms, diarrhea is a symptom of this disease and that it cannot be prevented by any currently available medication. Therefore, more dissemination of these relatively less known information is warranted to reduce disease transmission and recognition of more COVID-19 cases.

Our study identified several sociodemographic characteristics including male gender, higher educational level, living in town, better financial condition of the family and using internet as a source of information to be associated with having higher knowledge. Although tremendous improvements have been made in the past few decades, Bangladesh is still a male dominated society [15] and this could be partly responsible for males having relatively better knowledge. Females, less educated, poor, and rural people need to be especially targeted by the public health policies to make them more knowledgeable about COVID-19. Unless a coordinated effort of people from all the sociodemographic groups of the country is ensured, it will be extremely difficult to control the pandemic.
An online survey conducted in China approximately one month after the initial case detection in Wuhan, found that $90.8 \%$ of the online respondents were optimistic that the COVID-19 will finally be successfully controlled. Furthermore, higher COVID-19 knowledge score was positively associated with higher likelihood of being optimistic about this [5]. Apparently, compared to many other countries, China has been successful in controlling the local epidemic approximately within two months of the outbreak despite being the initial epicenter of COVID-19. Contrasting to this, and possibly a warning finding in our study, only $61.1 \%$ of the online non-medical participants had optimistic attitudes towards final control of COVID-19. The medical participants were even less optimistic (56\%). Rahman. A et al. reported even lower proportion of online respondents having optimistic attitudes (41.7\%) in Bangladesh [11]. Furthermore, we found that higher total knowledge score was positively associated with having negative attitude towards the final control of COVID-19. To explain this contradictory finding, we need to consider the differences in the extent of the measures taken by the authorities and people's behavior in both countries. As pointed out by [5], the extreme measures including the efficient lockdown of Wuhan by the Chinese authority might be responsible for having more confidence of the Chinese people on their authority and thereby more confidence in the successful control of the disease spread. Contrasting to this, the measures taken by Bangladeshi authorities have been criticized to be not as extreme as it should be to be able to successfully control the disease spread [16]. Moreover, there were many instances of mass gathering by people defying the government advise to avoid so which gained significant media attention (see [16] for a detailed discussion on this issue). Because of these events, it is tempting to speculate that the people with having more knowledge to become less optimistic about the final control of COVID-19 in Bangladesh.

\section{CONCLUSION}

Compared to the participants from the medical background, the non-medical participants showed significantly lower knowledge level of COVID-19. Although people had very good knowledge regarding the preventive practices, they were less aware about the facts that some COVID-19 patients may have no symptoms, diarrhea is a symptom of this disease and that it cannot be prevented by any currently available medication. Male gender, higher education, living in town/urban areas, good financial condition, and use of internet were positively associated with higher knowledge. However, higher knowledge score and use of internet as a source of information were associated with having less confidence in the final control of COVID19. Appropriate public health educational measures are warranted to increase awareness regarding the less known COVID-19 information with special focus on the less knowledgeable population groups. 


\section{LIMITATIONS}

One limitation of our study was the sampling techniques. As we had to rely on the authors' network for recruiting participants for phone survey, it suffered selection bias and we could not obtain a nationally representative sample for adult population. Therefore, our result might not be generalizable to the broader Bangladeshi population. Another limitation was that we could not quantify the financial condition of the participants with any formal scale to limit the phone call duration. Therefore, we had to rely on the "self-reported" financial condition.

Declaration of interest: The authors report no conflicts of interest.

Financial Disclosure: No financial support was received.

\section{REFERENCES}

1. The Worldometer. COVID-19 CORONAVIRUS PANDEMIC. 2020. Available at: https://www.worldo meters.info/coronavirus/ (Accessed 1 July 2020).

2. WHO. Coronavirus disease (COVID-19) advice for the public 2020. Available at: https://www.who.int/emergen cies/diseases/novel-coronavirus-2019/advice-for-public

3. Ajilore K, Atakiti I, Onyenankeya K. College students' knowledge, attitudes and adherence to public service announcements on Ebola in Nigeria: Suggestions for improving future Ebola prevention education programmes. Health Education Journal. 2017;76(6):64860. doi: 10.1177/0017896917710969.

4. Tachfouti N, Slama K, Berraho M, Nejjari C. The impact of knowledge and attitudes on adherence to tuberculosis treatment: a case-control study in a Moroccan region. Pan Afr Med J. 2012;12:52. PMID: 22937192.

5. Zhong B-L, Luo W, Li H-M, Zhang Q-Q, Liu X-G, Li W$\mathrm{T}$, et al. Knowledge, attitudes, and practices towards COVID-19 among Chinese residents during the rapid rise period of the COVID-19 outbreak: a quick online cross-sectional survey. Int J Biol Sci. 2020;16(10):174552. PMID: 32226294. doi: 10.7150/ijbs.45221.

6. Olum R, Chekwech G, Wekha G, Nassozi DR, Bongomin F. Coronavirus Disease-2019: Knowledge, Attitude, and Practices of Health Care Workers at Makerere University Teaching Hospitals, Uganda. Frontiers in Public Health. 2020;8(181). doi: 10.3389/fpubh.2020.00181.
7. Zegarra-Valdivia J, Vilca BNC, Guerrero RJA. Knowledge, perception and attitudes in Regard to COVID-19 Pandemic in Peruvian Population. 2020. doi: 10.31234/osf.io/kr9ya.

8. Abdelhafiz AS, Mohammed Z, Ibrahim ME, Ziady $\mathrm{HH}$, Alorabi M, et al. Knowledge, Perceptions, and Attitude of Egyptians Towards the Novel Coronavirus Disease (COVID-19). Journal of Community Health. 2020:1-10. doi: 10.1007/s10900-020-00827-7.

9. Austrian K, Pinchoff J, Tidwell JB, White C, Abuya T, Kangwana B, et al. COVID-19 related knowledge, attitudes, practices and needs of households in informal settlements in Nairobi, Kenya. 2020. doi: 10.2139/ssrn. 3576785 .

10. Azlan AA, Hamzah MR, Sern TJ, Ayub SH, Mohamad E. Public knowledge, attitudes and practices towards COVID-19: A cross-sectional study in Malaysia. PloS one. 2020;15(5):e0233668-e. PMID: 32437434. doi: 10.1371/journal.pone.0233668.

11. Rahman A, Sathi N. Knowledge, Attitude, and Preventive Practices toward COVID-19 among Bangladeshi Internet Users. Electronic Journal of General Medicine. 2020;17(5):em245. doi: 10.29333/ejgm/8223.

12. Bank W. Individuals using the Internet (\% of population) - Bangladesh, World, United Kingdom, United States. 2017. Available at: https://data.world bank.org/indicator/IT.NET.USER.ZS?locations=BD1W-GB-US

13. Taber KS. The Use of Cronbach's Alpha When Developing and Reporting Research Instruments in Science Education. Research in Science Education. 2018;48(6):1273-96. doi: 10.1007/s11165-016-9602-2.

14. Cowling BJ, Ali ST, Ng TWY, Tsang TK, Li JCM, et al. Impact assessment of non-pharmaceutical interventions against coronavirus disease 2019 and influenza in Hong Kong: an observational study. The Lancet Public health. 2020;5(5):e279-e88. PMID: 32311320. PMCID: PMC7164922. doi: 10.1016/S2468-2667(20)30090-6.

15. Ferdaush J. Gender Inequality in Bangladesh. 2019.

16. Anwar S, Nasrullah M, Hosen MJ. COVID-19 and Bangladesh: Challenges and How to Address Them. Frontiers in Public Health. 2020;8(154). doi: 10.3389/fpubh.2020.00154. 


\section{APPENDIX 1}

\section{Supplementary Methods}

\section{Phone survey}

Due to the rapid spread of COVID-19 and significant disruption (termed as "lockdown" by many, but not officially) of different areas of Bangladesh during our study period, it was not feasible to conduct a community-based national sampling survey. Therefore, we had to rely on the authors' network to recruit participants. For better representation of the diverse population and to cover all the administrative divisions of Bangladesh, we first formed a research group (of 30) with members studied/studying/worked/working in various universities/institutes throughout the country. Members were trained to conduct the phone survey with same instructional videos and materials so that everyone could follow a similar approach while conducting the survey. Inclusion criteria were a) persons giving consent to participate, and b) at least 18 years old. Exclusion criteria were: a) persons not giving consent, b) persons who could not communicate well, c) researcher's family members, d) researcher's relatives/friends/colleagues with whom the researcher previously discussed about COVID-19 to make them aware, e) other family members/friends/colleagues living together with already included participant, and $f$ ) doctors/nurses/medical students and family members living with them. The researchers used their acquaintances, acquaintances of family members or friends or colleagues, and acquaintances of acquaintances to recruit a wide range of participants of different age groups, geographic locations, financial conditions, and educational backgrounds. When we requested our acquaintances to suggest some of their acquaintances to be included in our study, they were requested not to disclose the survey questions asked from them during their participation in our survey. Conversations with the participants were made through phone calls. At the beginning, we obtained informed verbal consent. After that, we asked whether they had heard about the recent outbreak of COVID-19 or SARS-CoV-2. If they answered "yes", then we proceeded with the questionnaire which took on average 10-12 minutes to complete. If the participants appeared to be not communicating well enough or not understanding the questions reasonably, we excluded them from the survey. After the end of the interview, they were informed briefly about the important information regarding COVID-19 and the correct answers to the questions asked.

\section{Online Survey}

The online survey was done with the same questionnaire with additional attitude questions that were not covered in the phone survey (to minimize phone call duration). The questionnaire was created on Google Forms and distributed through social media. The online link was posted and reposted on the Facebook timeline of the researchers, different Facebook groups, sent through friends or acquaintances through Facebook messenger or WhatsApp. Besides, the researchers requested their acquaintances to post/share the survey link on their Facebook timeline or social media apps or Facebook groups. The link was accompanied by a summary of the study to allow the participants to make an informed decision. We requested Bangladeshi citizens who understood the nature of the study, was willing to participate, and was not surveyed by the phone call to attempt the questionnaire. At the beginning of the survey, they were asked whether they had heard about the recent outbreak of COVID-19 or SARS-CoV-2. If they answered "yes", then the questions of the questionnaire appeared section by section and at the end of the survey, they were provided with important information regarding COVID-19 and referred to the website of WHO and Institute of Epidemiology, Disease Control and Research (IEDCR) of Bangladesh for further information. If they answered "no", they were directly forwarded to the last information page.

\section{Questionnaire}

The questionnaire was developed based on the information provided by the WHO, IEDCR, and Centers for Disease Control and Prevention (CDC) of USA to the general public, latest scientific evidence from literature, and previously published similar study [1]. Both English and Bangla versions of the questionnaire were agreed by a panel comprising of one clinical professor, two epidemiologists, five physicians, two medical students, and four non-medical researchers. It was tested by a pilot survey from 20 participants through phone call to ensure that all the questions were clearly understood. It is worth mentioning that there are several dialects of Bangla language spoken throughout the country. During the phone survey, sometimes researchers had to conduct survey using the local dialect.

\section{Questionnaire used in the present study}

Section-1: Source of information regarding COVID-19 or SARS-CoV-2 (can choose more than one)

a. Television b. Printed newspapers c. Internet (including social media e.g., Facebook)

d. From other people e. Other means

Knowledge and attitude questions

Section-2A: Questions related to the knowledge of the disease (KD)

KD01 Some patients may have no symptoms (true)

KD02 Fever is a common symptom of this disease (true)

KD03 Cough is a common symptom of this disease (true)

KD04 Patients with this disease can suffer from shortness of breath or difficulty in breathing (true)

KD05 Some patients with this disease can have tiredness, sore throat, headaches, body aches (true)

KD06 Some patients with this disease can have diarrhea (true) 
KD07 This disease can be completely prevented by taking antibiotics or other medicine (false)

KD08 It can take up to 14 days after being infected to develop symptoms (true)

KD09 The disease can spread from an infected person to others even before symptoms develop (true)

KD10 This virus can spread from an infected person through talking or breathing (true)

KD11 This virus can spread from an infected person through coughing (true)

KD12 People can get infected by touching objects or surfaces contaminated with this virus, and then touching their eyes, nose or mouth without cleaning hands (true)

KD13 All the patients with this disease die (false)

KD14 Older persons and persons with heart disease, lung disease, diabetes are at high risk of developing severe COVID-19 disease (true)

Section-2B: Questions related to the knowledge of the preventive practices $(\mathrm{KP})$

KP01 Younger persons do not need to follow any precautionary measures to prevent the disease (false)

KP02 Washing hands frequently and thoroughly with soap or alcohol-based hand sanitizers reduces the risk of being infected by this virus (true)

KP03 To reduce the risk of being infected by this virus, one should avoid touching eyes, nose, mouth with uncleaned hands (true)

KP04 To reduce the spread of this virus, one should cover his mouth and nose with bent-elbow or tissue paper or handkerchief when coughing or sneezing (true)

KP05 When this virus spreads in an area, people should stay home as much as possible to reduce the spread of this disease (true)

KP06 Infected person should wear mask to reduce the spread of this virus (true)

Section-3: Questions related to attitude towards COVID-19 (only for online survey)

A1 Do you think that this new coronavirus will finally be under control completely?

A2 "This virus is created by humans" - this kind of discourse is heard. Do you believe that it is true?

\section{References}

1. Zhong B-L, Luo W, Li H-M, Zhang Q-Q, Liu X-G, Li WT, Li Y: Knowledge, attitudes, and practices towards COVID-19 among Chinese residents during the rapid rise period of the COVID-19 outbreak: a quick online cross-sectional survey. Int J Biol Sci 2020, 16(10):17451752. doi: 10.7150/ijbs.45221.

\section{APPENDIX 2}

Distribution of the participants into the administrative divisions of Bangladesh

Distribution of the participants according to the eight administrative divisions of Bangladesh

\begin{tabular}{|c|c|c|c|c|c|}
\hline \multirow[t]{2}{*}{$\begin{array}{l}\text { Administrative } \\
\text { divisions }\end{array}$} & $\begin{array}{l}\text { Phone, } \\
\text { n=1426 }\end{array}$ & $\begin{array}{c}\text { Online } \\
\text { non- } \\
\text { medical, } \\
\text { n=1097 }\end{array}$ & $\begin{array}{c}\text { Online } \\
\text { medical, } \\
n=382\end{array}$ & \multirow[t]{2}{*}{$\begin{array}{l}\chi^{2} P- \\
\text { value }\end{array}$} & $\begin{array}{c}\text { Total, } \\
\mathrm{n}=\mathbf{2 9 0 5}\end{array}$ \\
\hline & n (\%) & n (\%) & n (\%) & & n (\%) \\
\hline Chattogram & $\begin{array}{c}610 \\
(42.8)\end{array}$ & $488(44.5)$ & $\begin{array}{c}200 \\
(52.4)\end{array}$ & \multirow{8}{*}{$<0.001$} & $\begin{array}{c}1298 \\
(44.7)\end{array}$ \\
\hline Dhaka & $\begin{array}{c}325 \\
(22.8)\end{array}$ & $408(37.2)$ & $\begin{array}{c}119 \\
(31.2)\end{array}$ & & $\begin{array}{c}852 \\
(29.3)\end{array}$ \\
\hline Khulna & $56(3.9)$ & $57(5.2)$ & $20(5.2)$ & & $\begin{array}{c}133 \\
(4.6)\end{array}$ \\
\hline Mymensingh & $\begin{array}{c}215 \\
(15.1)\end{array}$ & $51(4.6)$ & $10(2.6)$ & & $\begin{array}{l}276 \\
(9.5)\end{array}$ \\
\hline Rajshahi & $70(4.9)$ & $39(3.6)$ & $9(2.4)$ & & $\begin{array}{c}118 \\
(4.1)\end{array}$ \\
\hline Sylhet & $47(3.3)$ & $27(2.5)$ & $6(1.6)$ & & $80(2.8)$ \\
\hline Barishal & $68(4.8)$ & $14(1.3)$ & $10(2.6)$ & & $92(3.2)$ \\
\hline Rangpur & $35(2.5)$ & $13(1.2)$ & $8(2.1)$ & & $56(1.9)$ \\
\hline
\end{tabular}

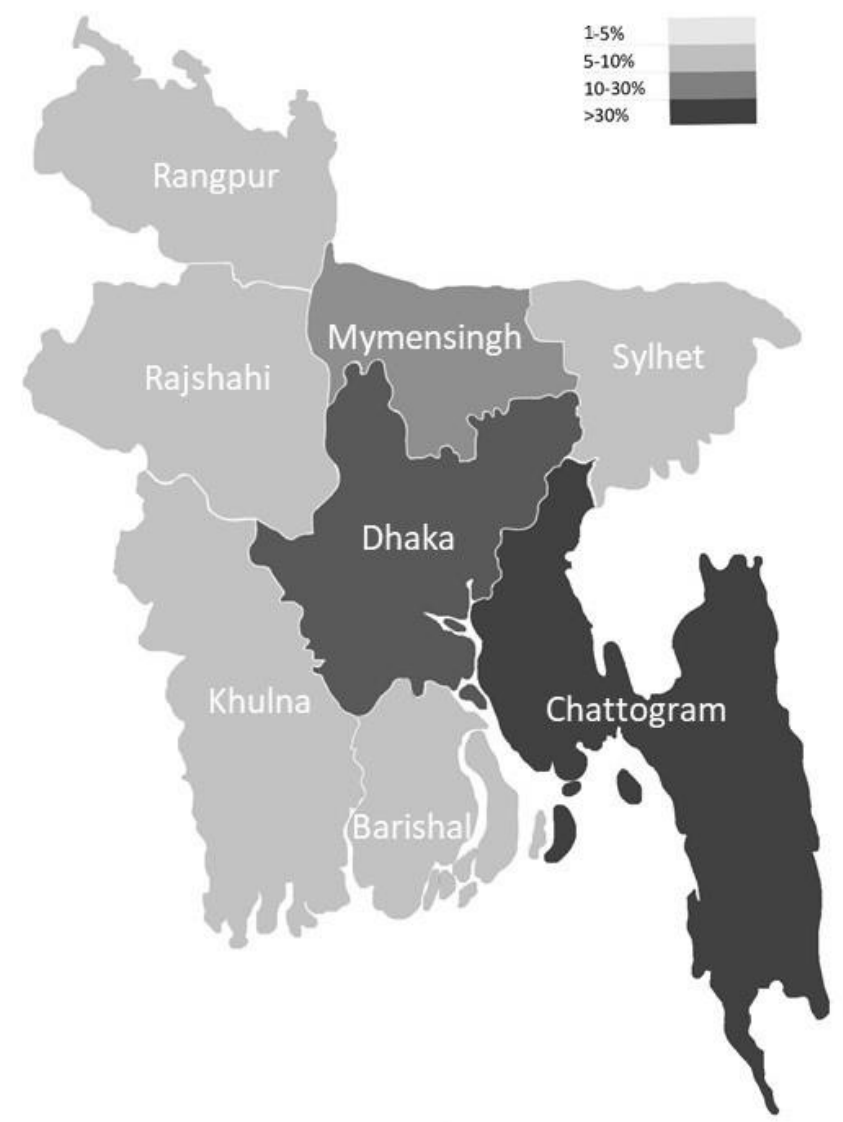




\section{APPENDIX 3}

Responses to the attitude question A1 (Do you think that this new coronavirus will finally be under control completely?) by sociodemographic characteristics and source of information

\begin{tabular}{|c|c|c|c|c|c|c|c|}
\hline & \multicolumn{3}{|c|}{$\begin{array}{l}\text { Online non-medical, } \\
\qquad \mathrm{n}=1097\end{array}$} & \multicolumn{3}{|c|}{ Online medical, $n=382$} \\
\hline & & Yes & No & $\begin{array}{l}\text { Don't } \\
\text { know }\end{array}$ & Yes & No & $\begin{array}{l}\text { Don't } \\
\text { know }\end{array}$ \\
\hline & & n (\%) & n (\%) & n (\%) & n (\%) & n (\%) & n (\%) \\
\hline \multicolumn{8}{|c|}{ Socio-demographic characteristics } \\
\hline \multirow{3}{*}{ Age (years) } & $\geq 18-<35$ & $\begin{array}{c}546 \\
(60.6)\end{array}$ & $\begin{array}{c}94 \\
(10.4)\end{array}$ & \begin{tabular}{|l|}
261 \\
$(29)$
\end{tabular} & $\begin{array}{c}196 \\
(56.5)\end{array}$ & $59(17)$ & $\begin{array}{c}92 \\
(26.5)\end{array}$ \\
\hline & $\geq 35-<55$ & $\begin{array}{l}109 \\
(63)\end{array}$ & $\begin{array}{c}23 \\
(13.3)\end{array}$ & $\begin{array}{c}41 \\
(23.7)\end{array}$ & $14(50)$ & $2(7.1)$ & $\begin{array}{c}12 \\
(42.9)\end{array}$ \\
\hline & $\geq 55$ & $\begin{array}{c}15 \\
(65.2)\end{array}$ & $2(8.7)$ & $6(26.1)$ & $4(57.1)$ & $2(28.6)$ & $1(14.3)$ \\
\hline \multirow{2}{*}{ Gender } & Male & $\begin{array}{c}472 \\
(63.5)\end{array}$ & $\begin{array}{c}86 \\
(11.6)\end{array}$ & $\begin{array}{c}185 \\
(24.9)\end{array}$ & $\begin{array}{l}103 \\
(64)\end{array}$ & $\begin{array}{c}32 \\
(19.9)\end{array}$ & $\begin{array}{c}26 \\
(16.1)\end{array}$ \\
\hline & Female & $\begin{array}{c}198 \\
(55.9)\end{array}$ & $33(9.3)$ & $\begin{array}{c}123 \\
(34.7)\end{array}$ & $\begin{array}{c}111 \\
(50.2)\end{array}$ & $31(14)$ & $\begin{array}{c}79 \\
(35.7)\end{array}$ \\
\hline \multirow{4}{*}{ Education } & $\leq$ Grade 5 & $0(0)$ & $0(0)$ & $2(100)$ & & & \\
\hline & $\begin{array}{c}\text { Grade } 6 \text { to } \\
12\end{array}$ & $\begin{array}{c}36 \\
(55.4)\end{array}$ & $5(7.7)$ & $\begin{array}{c}24 \\
(36.9)\end{array}$ & & & \\
\hline & $\begin{array}{l}>\text { Grade } 12 \\
\text { to Bachelor }\end{array}$ & $\begin{array}{c}347 \\
(60.8)\end{array}$ & $\begin{array}{c}66 \\
(11.6)\end{array}$ & $\begin{array}{c}158 \\
(27.7)\end{array}$ & $\begin{array}{c}157 \\
(58.4)\end{array}$ & $\begin{array}{c}41 \\
(15.2)\end{array}$ & $\begin{array}{c}71 \\
(26.4)\end{array}$ \\
\hline & $\begin{array}{c}>\text { Bachelor } \\
\text { to Master or } \\
\text { above }\end{array}$ & $\begin{array}{c}287 \\
(62.5)\end{array}$ & $\begin{array}{c}48 \\
(10.5)\end{array}$ & $\begin{array}{l}124 \\
(27)\end{array}$ & $\begin{array}{c}57 \\
(50.4)\end{array}$ & $\begin{array}{c}22 \\
(19.5)\end{array}$ & $\begin{array}{c}34 \\
(30.1)\end{array}$ \\
\hline \multirow{3}{*}{$\begin{array}{l}\text { Lived } \\
\text { mostly in } \\
\text { last } 4 \\
\text { months }\end{array}$} & Village & $\begin{array}{c}79 \\
(62.2)\end{array}$ & $12(9.4)$ & $\begin{array}{c}36 \\
(28.3)\end{array}$ & $\begin{array}{c}21 \\
(55.3)\end{array}$ & $8(21.1)$ & $9(23.7)$ \\
\hline & Urban/town & $\begin{array}{c}578 \\
(60.8)\end{array}$ & $\begin{array}{c}105 \\
(11.1)\end{array}$ & $\begin{array}{c}267 \\
(28.1)\end{array}$ & $\begin{array}{c}191 \\
(56.2)\end{array}$ & $\begin{array}{c}55 \\
(16.2)\end{array}$ & $\begin{array}{c}94 \\
(27.6)\end{array}$ \\
\hline & Other & $13(65)$ & $2(10)$ & $5(25)$ & $2(50)$ & $0(0)$ & $2(50)$ \\
\hline \multirow{3}{*}{$\begin{array}{l}\text { Financial } \\
\text { condition }\end{array}$} & Poor & $\begin{array}{c}25 \\
(55.6)\end{array}$ & $2(4.4)$ & $18(40)$ & & & \\
\hline & Middle-class & $\begin{array}{c}623 \\
(61.6)\end{array}$ & $\begin{array}{c}110 \\
(10.9)\end{array}$ & $\begin{array}{c}279 \\
(27.6)\end{array}$ & $\begin{array}{c}197 \\
(56.1)\end{array}$ & $56(16)$ & $\begin{array}{c}98 \\
(27.9)\end{array}$ \\
\hline & Rich & $22(55)$ & $7(17.5)$ & $\begin{array}{c}11 \\
(27.5)\end{array}$ & $\begin{array}{c}17 \\
(54.8)\end{array}$ & $7(22.6)$ & $7(22.6)$ \\
\hline \multicolumn{8}{|c|}{ Source of information } \\
\hline \multirow{2}{*}{ Television } & Yes & $\begin{array}{c}347 \\
(61.4)\end{array}$ & \begin{tabular}{|c|}
58 \\
$(10.3)$
\end{tabular} & $\begin{array}{c}160 \\
(28.3)\end{array}$ & $\begin{array}{c}104 \\
(56.8)\end{array}$ & $\begin{array}{c}32 \\
(17.5)\end{array}$ & $\begin{array}{c}47 \\
(25.7)\end{array}$ \\
\hline & No & $\begin{array}{c}323 \\
(60.7)\end{array}$ & $\begin{array}{c}61 \\
(11.5)\end{array}$ & $\begin{array}{c}148 \\
(27.8)\end{array}$ & $\begin{array}{c}110 \\
(55.3)\end{array}$ & $\begin{array}{c}31 \\
(15.6)\end{array}$ & $\begin{array}{c}58 \\
(29.1)\end{array}$ \\
\hline \multirow{2}{*}{ Newspaper } & Yes & $\begin{array}{c}213 \\
(63.8)\end{array}$ & $\begin{array}{c}39 \\
(11.7)\end{array}$ & $\begin{array}{c}82 \\
(24.6)\end{array}$ & $\begin{array}{c}68 \\
(56.7)\end{array}$ & $\begin{array}{c}20 \\
(16.7)\end{array}$ & $\begin{array}{c}32 \\
(26.7)\end{array}$ \\
\hline & No & $\begin{array}{c}457 \\
(59.9)\end{array}$ & $\begin{array}{c}80 \\
(10.5)\end{array}$ & $\begin{array}{c}226 \\
(29.6)\end{array}$ & $\begin{array}{c}146 \\
(55.7)\end{array}$ & $\begin{array}{c}43 \\
(16.4)\end{array}$ & $\begin{array}{c}73 \\
(27.9) \\
\end{array}$ \\
\hline \multirow{2}{*}{ Internet } & Yes & $\begin{array}{c}565 \\
(59.8)\end{array}$ & $\begin{array}{c}112 \\
(11.9)\end{array}$ & $\begin{array}{c}268 \\
(28.4)\end{array}$ & $\begin{array}{c}189 \\
(56.1)\end{array}$ & $54(16)$ & $\begin{array}{c}94 \\
(27.9)\end{array}$ \\
\hline & No & $\begin{array}{c}105 \\
(69.1)\end{array}$ & $7(4.6)$ & $\begin{array}{c}40 \\
(26.3)\end{array}$ & $\begin{array}{c}25 \\
(55.6)\end{array}$ & $9(20)$ & $\begin{array}{c}11 \\
(24.4)\end{array}$ \\
\hline \multirow{2}{*}{$\begin{array}{l}\text { Other } \\
\text { people }\end{array}$} & Yes & $\begin{array}{c}99 \\
(60.7)\end{array}$ & $\begin{array}{c}22 \\
(13.5)\end{array}$ & $\begin{array}{c}42 \\
(25.8)\end{array}$ & $\begin{array}{c}45 \\
(63.4)\end{array}$ & $8(11.3)$ & $\begin{array}{c}18 \\
(25.4)\end{array}$ \\
\hline & No & $\begin{array}{c}571 \\
(61.1)\end{array}$ & $\begin{array}{c}97 \\
(10.4)\end{array}$ & $\begin{array}{c}266 \\
(28.5)\end{array}$ & $\begin{array}{c}169 \\
(54.3)\end{array}$ & $\begin{array}{c}55 \\
(17.7)\end{array}$ & $87(28)$ \\
\hline \multirow{2}{*}{ Other ways } & Yes & $\begin{array}{c}28 \\
(58.3)\end{array}$ & $6(12.5)$ & $\begin{array}{c}14 \\
(29.2)\end{array}$ & $\begin{array}{c}22 \\
(52.4)\end{array}$ & $5(11.9)$ & $\begin{array}{c}15 \\
(35.7)\end{array}$ \\
\hline & No & $\begin{array}{c}642 \\
(61.2)\end{array}$ & $\begin{array}{c}113 \\
(10.8)\end{array}$ & $\begin{array}{l}294 \\
(28)\end{array}$ & $\begin{array}{c}192 \\
(56.5)\end{array}$ & $\begin{array}{c}58 \\
(17.1) \\
\end{array}$ & $\begin{array}{c}90 \\
(26.5)\end{array}$ \\
\hline \multicolumn{2}{|c|}{ Total } & $\begin{array}{c}670 \\
(61.1)\end{array}$ & $\begin{array}{c}119 \\
(10.8)\end{array}$ & $\begin{array}{c}308 \\
(28.1)\end{array}$ & $\begin{array}{l}214 \\
(56)\end{array}$ & $\begin{array}{c}63 \\
(16.5)\end{array}$ & $\begin{array}{c}105 \\
(27.5)\end{array}$ \\
\hline
\end{tabular}

\section{APPENDIX 4}

Responses to the attitude question A2 ("This virus is created by humans" - this kind of discourse is heard. Do you believe that it is true?) by sociodemographic characteristics and source of information

\begin{tabular}{|c|c|c|c|c|c|c|c|}
\hline & \multicolumn{3}{|c|}{$\begin{array}{l}\text { Online non-medical, } \\
\qquad \mathrm{n}=1097\end{array}$} & \multicolumn{3}{|c|}{ Online medical, $\mathrm{n}=382$} \\
\hline & & Yes & No & $\begin{array}{l}\text { Don't } \\
\text { know }\end{array}$ & Yes & No & $\begin{array}{l}\text { Don't } \\
\text { know }\end{array}$ \\
\hline & & n (\%) & n (\%) & n (\%) & n (\%) & n (\%) & n (\%) \\
\hline \multicolumn{8}{|c|}{ Socio-demographic characteristics } \\
\hline \multirow{3}{*}{ Age (years) } & $\geq 18-<35$ & $\begin{array}{c}167 \\
(18.5)\end{array}$ & $\begin{array}{c}231 \\
(25.6)\end{array}$ & $\begin{array}{c}503 \\
(55.8)\end{array}$ & $\begin{array}{c}64 \\
(18.4)\end{array}$ & $\begin{array}{c}123 \\
(35.4)\end{array}$ & $\begin{array}{c}160 \\
(46.1)\end{array}$ \\
\hline & $\geq 35-<55$ & $38(22)$ & $45(26)$ & $90(52)$ & $5(17.9)$ & $\begin{array}{c}12 \\
(42.9)\end{array}$ & $\begin{array}{c}11 \\
(39.3)\end{array}$ \\
\hline & $\geq 55$ & $5(21.7)$ & $4(17.4)$ & $\begin{array}{c}14 \\
(60.9)\end{array}$ & $0(0)$ & $3(42.9)$ & $4(57.1)$ \\
\hline \multirow{2}{*}{ Gender } & Male & $\begin{array}{c}146 \\
(19.7)\end{array}$ & $\begin{array}{c}194 \\
(26.1)\end{array}$ & $\begin{array}{c}403 \\
(54.2)\end{array}$ & $\begin{array}{c}26 \\
(16.1)\end{array}$ & $\begin{array}{c}68 \\
(42.2)\end{array}$ & $\begin{array}{c}67 \\
(41.6)\end{array}$ \\
\hline & Female & $\begin{array}{c}64 \\
(18.1)\end{array}$ & $\begin{array}{c}86 \\
(24.3)\end{array}$ & $\begin{array}{c}204 \\
(57.6)\end{array}$ & $\begin{array}{c}43 \\
(19.5)\end{array}$ & $\begin{array}{c}70 \\
(31.7)\end{array}$ & $\begin{array}{c}108 \\
(48.9)\end{array}$ \\
\hline \multirow{4}{*}{ Education } & $\leq$ Grade 5 & $0(0)$ & $0(0)$ & $2(100)$ & & & \\
\hline & $\begin{array}{l}\text { Grade } 6 \text { to } \\
12\end{array}$ & $\begin{array}{c}17 \\
(26.2)\end{array}$ & $\begin{array}{c}15 \\
(23.1)\end{array}$ & $\begin{array}{c}33 \\
(50.8)\end{array}$ & & & \\
\hline & $\begin{array}{l}>\text { Grade } 12 \\
\text { to Bachelor }\end{array}$ & $\begin{array}{c}112 \\
(19.6)\end{array}$ & $143(25)$ & $\begin{array}{c}316 \\
(55.3)\end{array}$ & $\begin{array}{c}50 \\
(18.6)\end{array}$ & $\begin{array}{c}95 \\
(35.3)\end{array}$ & $\begin{array}{c}124 \\
(46.1)\end{array}$ \\
\hline & $\begin{array}{c}>\text { Bachelor } \\
\text { to Master or } \\
\text { above }\end{array}$ & $\begin{array}{c}81 \\
(17.6)\end{array}$ & $\begin{array}{c}122 \\
(26.6)\end{array}$ & $\begin{array}{c}256 \\
(55.8)\end{array}$ & $\begin{array}{c}19 \\
(16.8)\end{array}$ & $\begin{array}{c}43 \\
(38.1)\end{array}$ & $\begin{array}{c}51 \\
(45.1)\end{array}$ \\
\hline \multirow{3}{*}{$\begin{array}{l}\text { Lived } \\
\text { mostly in } \\
\text { last } 4 \\
\text { months }\end{array}$} & Village & $\begin{array}{c}23 \\
(18.1)\end{array}$ & $\begin{array}{c}32 \\
(25.2)\end{array}$ & $\begin{array}{c}72 \\
(56.7)\end{array}$ & $\begin{array}{c}13 \\
(34.2)\end{array}$ & $\begin{array}{c}14 \\
(36.8)\end{array}$ & $\begin{array}{c}11 \\
(28.9)\end{array}$ \\
\hline & Urban/town & $\begin{array}{c}184 \\
(19.4)\end{array}$ & $\begin{array}{c}239 \\
(25.2)\end{array}$ & $\begin{array}{c}527 \\
(55.5)\end{array}$ & $\begin{array}{c}55 \\
(16.2)\end{array}$ & $\begin{array}{c}122 \\
(35.9)\end{array}$ & $\begin{array}{c}163 \\
(47.9)\end{array}$ \\
\hline & Other & $3(15)$ & $9(45)$ & $8(40)$ & $1(25)$ & $2(50)$ & $1(25)$ \\
\hline \multirow{3}{*}{$\begin{array}{l}\text { Financial } \\
\text { condition }\end{array}$} & Poor & $\begin{array}{c}11 \\
(24.4)\end{array}$ & $\begin{array}{c}14 \\
(31.1)\end{array}$ & $\begin{array}{c}20 \\
(44.4)\end{array}$ & & & \\
\hline & Middle-class & $\begin{array}{c}191 \\
(18.9)\end{array}$ & $\begin{array}{c}258 \\
(25.5)\end{array}$ & $\begin{array}{c}563 \\
(55.6)\end{array}$ & $\begin{array}{c}59 \\
(16.8)\end{array}$ & $130(37)$ & $\begin{array}{c}162 \\
(46.2)\end{array}$ \\
\hline & Rich & $8(20)$ & $8(20)$ & $24(60)$ & $\begin{array}{c}10 \\
(32.3)\end{array}$ & $8(25.8)$ & $\begin{array}{c}13 \\
(41.9)\end{array}$ \\
\hline \multicolumn{8}{|c|}{ Source of information } \\
\hline \multirow{2}{*}{ Television } & Yes & $\begin{array}{c}103 \\
(18.2)\end{array}$ & $\begin{array}{c}136 \\
(24.1)\end{array}$ & $\begin{array}{c}326 \\
(57.7) \\
\end{array}$ & $\begin{array}{c}36 \\
(19.7)\end{array}$ & $\begin{array}{c}62 \\
(33.9)\end{array}$ & $\begin{array}{c}85 \\
(46.4)\end{array}$ \\
\hline & No & $\begin{array}{c}107 \\
(20.1)\end{array}$ & $\begin{array}{c}144 \\
(27.1)\end{array}$ & $\begin{array}{c}281 \\
(52.8)\end{array}$ & $\begin{array}{c}33 \\
(16.6)\end{array}$ & $\begin{array}{c}76 \\
(38.2) \\
\end{array}$ & $\begin{array}{c}90 \\
(45.2)\end{array}$ \\
\hline \multirow{2}{*}{ Newspaper } & Yes & $60(18)$ & $\begin{array}{c}78 \\
(23.4) \\
\end{array}$ & $\begin{array}{c}196 \\
(58.7)\end{array}$ & $24(20)$ & $\begin{array}{c}38 \\
(31.7) \\
\end{array}$ & $\begin{array}{c}58 \\
(48.3)\end{array}$ \\
\hline & No & $\begin{array}{c}150 \\
(19.7)\end{array}$ & $\begin{array}{c}202 \\
(26.5)\end{array}$ & $\begin{array}{c}411 \\
(53.9)\end{array}$ & $\begin{array}{c}45 \\
(17.2)\end{array}$ & $\begin{array}{c}100 \\
(38.2)\end{array}$ & $\begin{array}{c}117 \\
(44.7)\end{array}$ \\
\hline \multirow{2}{*}{ Internet } & Yes & $\begin{array}{c}178 \\
(18.8)\end{array}$ & $\begin{array}{c}240 \\
(25.4)\end{array}$ & $\begin{array}{c}527 \\
(55.8)\end{array}$ & $\begin{array}{c}63 \\
(18.7)\end{array}$ & $\begin{array}{c}116 \\
(34.4)\end{array}$ & $\begin{array}{c}158 \\
(46.9)\end{array}$ \\
\hline & No & $\begin{array}{c}32 \\
(21.1)\end{array}$ & $\begin{array}{c}40 \\
(26.3)\end{array}$ & $\begin{array}{c}80 \\
(52.6)\end{array}$ & $6(13.3)$ & $\begin{array}{c}22 \\
(48.9)\end{array}$ & $\begin{array}{c}17 \\
(37.8)\end{array}$ \\
\hline \multirow{2}{*}{$\begin{array}{l}\text { Other } \\
\text { people }\end{array}$} & Yes & $\begin{array}{c}22 \\
(13.5)\end{array}$ & $\begin{array}{c}41 \\
(25.2)\end{array}$ & $\begin{array}{c}100 \\
(61.3)\end{array}$ & $\begin{array}{c}13 \\
(18.3)\end{array}$ & $27(38)$ & $\begin{array}{c}31 \\
(43.7)\end{array}$ \\
\hline & No & $\begin{array}{c}188 \\
(20.1)\end{array}$ & $\begin{array}{c}239 \\
(25.6)\end{array}$ & $\begin{array}{c}507 \\
(54.3)\end{array}$ & $56(18)$ & $\begin{array}{c}111 \\
(35.7)\end{array}$ & $\begin{array}{c}144 \\
(46.3)\end{array}$ \\
\hline \multirow{2}{*}{ Other ways } & Yes & $8(16.7)$ & $\begin{array}{c}11 \\
(22.9)\end{array}$ & $\begin{array}{c}29 \\
(60.4)\end{array}$ & $7(16.7)$ & $\begin{array}{c}16 \\
(38.1)\end{array}$ & $\begin{array}{c}19 \\
(45.2)\end{array}$ \\
\hline & No & $\begin{array}{c}202 \\
(19.3)\end{array}$ & $\begin{array}{c}269 \\
(25.6)\end{array}$ & $\begin{array}{c}578 \\
(55.1)\end{array}$ & $\begin{array}{c}62 \\
(18.2)\end{array}$ & $\begin{array}{c}122 \\
(35.9)\end{array}$ & $\begin{array}{c}156 \\
(45.9)\end{array}$ \\
\hline \multicolumn{2}{|c|}{ Total } & $\begin{array}{c}210 \\
(19.1)\end{array}$ & $\begin{array}{c}280 \\
(25.5)\end{array}$ & $\begin{array}{c}607 \\
(55.3)\end{array}$ & $\begin{array}{c}69 \\
(18.1)\end{array}$ & $\begin{array}{c}138 \\
(36.1)\end{array}$ & $\begin{array}{c}175 \\
(45.8)\end{array}$ \\
\hline
\end{tabular}

